\title{
King Zumbi and the Malê Movement in Brazil
}

Three great regions of America deserve a Muslim's attention because of their Islamic past: Brazil in South America; the Caribbean, which scarcely has been explored in this respect; and the United States. Over 12 percent of the United States' population, and even more in the Caribbean, is of African origin, whereas Brazil has a similar or greater proportion of African descent.

The enslavement and transportation of Africans to the New World continued for another three or four centuries after the region's indigenous Indian populations had either been killed off or driven into the plains and woods. While knowledge of the original African Muslims in North America is vaguely acknowledged, research is still required on the West Indies. Brazil's case, however, is clearer due to its proud history of the Palmares republic, which almost achieved its freedom in the seventeenth century, and the clearly Islamic nineteenth-century Malê movement. As a postscript, the Canudos movement in 1897 also contained some Islamic features.

In the Spanish colonies, the decline of the indigenous Indian populations began quickly. To offset this development, Bartolomé de Las Casas (14741566), Bishop of Chiapas, Mexico, suggested the importation of enslaved Africans to the new colonies, where they could then be converted to Christianity. Few persons have exercised such a baneful effect on society as this man, who is often called the "Apostle of the Indies." However, others knew him as the "Enslaver of Africans," especially the Muslims, who he called "Moors." These facts of African slavery apply to almost all of the Atlantic coast of the Americas, from Maryland and Virginia to Argentina, as well as to some countries along the Pacific coast such as Ecuador and Peru. If this aspect of Muslim history and the Islamic heritage is to be preserved for human history, we need to devote more study to it.

This tragedy began in the sixteenth century and, after more than four hundred years, its effects are still apparent. If those Africans caught and sold into slavery were educated, as many of them were, they were generally Muslims and wrote in Arabic. Thus, many educated and literate slaves kept the records for their sometimes illiterate plantation masters, who often could not read or make any mathematical calculations, let alone handle formal bookkeeping.

In 1532, the first permanent European settlement was established in Brazil, a country which since that date has never been wholly cut off from West Africa: even today trade is carried on with the Guinea coast. Yoruba influence from Nigeria and Benin has been almost as pervasive in some regions of Bra- 
zil as Portuguese influence. Nagô means "Yoruba," and Gâgo refers to the Ewe from Dahomey or modern Benin and Togoland. Though there are some traces, the use of these native African languages has disappeared and expressions generally remain only as vocabulary items.

Hausa slaves, known as Ûssa in Brazil, were generally Muslims who retained their faith for as long as they could and at times were able to convert other captives to it. Alufa is the term for a black imam in Rio de Janeiro; Lessano is a Brazilian term for an imam or a leader in prayer; and Musulmi (and also Malê) is the name for Muslims in the state of Bahia. Malê also has the possible meaning of one who is originally from Mali, or it could be from a word for Muslims in the Yoruba language. The phrase fazer sala (or sara in a variant of the Arabic saläh) means "praying" in Bahia.

The Yoruba from the coastal areas of the Bight of Benin in the Gulf of Guinea were known in Brazil as Nagôs. They are now found mainly in the state of Bahia, where their influence is still felt. Sudani groups from the northlands were the Fulani and Ûssa peoples. The Nagôs and Ûssas in Brazil were thus Yoruba and Hausa slaves respectively. The Minas and Ewe slaves came from the Gold Coast; King Zumbi of Palmares was most likely one of their descendants. The name Male is used to designate Mandingos from the ancient empire of Mali, although imali is also a Yoruba word for Muslims. Those who came from Angola were known as Bantus, and those from the Niger Delta as Calabars (or Ibos). These different African "nations" were kept apart in Brazil, and their tribal rivalries were fostered in order to keep them in dissension. The Portuguese also segregated their slaves along ethnic lines or into guilds in order to promote divisions among them.

Since many Africans were known to be Muslims, this policy continued the Christian reconquista of Spain and Portugal by projecting it overseas. Slave owners feared some of the Muslim slaves, such as the Jalofos, the Wollofs, and the Mandingos, for these captives had faith and, as believers, possessed moral strength and character. Thousands of West African villagers, or more likely millions when the total number is added up, who ranged from common farmers to artisans and merchants were seized in brutal slave raids and sent to the New World. Frequently, the prisoners taken in these raids were Muslims from the inland kingdoms of Songhai, Hausaland, and Mali.

The Brazilian jaqunços or sertanejos then began to develop as a new breed of men who were truly American, even though they were a disorderly lot at first-mainly outlaws in the backwoods prospecting for gold and diamonds and grubbing for food. They became true proletarians as they built their red-clay towns in the Brazilian wilds and continued to observe African tribal customs. Religious ceremonies known as candomblés, similar to voodoo ceremonies in Haiti or Cuba, arose in Bahia and created a lost world where ritual dances were performed before palm-thatched huts. These ceremonies 
contained elements of many cults, most of them animist in origin, and represented a vigorous popular movement whose rituals were conducted in a serious and dignified manner. The candomble itself is said to be of Yoruban origin from what is now southern Nigeria, and thus pagan or animist.

Life in the senzalas (slave quarters) debased the Africans who were forced to live in them, as do the favelas (slums, shatnytowns) surrounding present-day Rio de Janeiro and São Paulo (or those of Havana or Harlem), whereas the quilombos provided them with some dignity. Cuisine and cooking, if they can be differentiated, were influenced by these forced migrants who had to labor in plantation kitchens, where they adapted typically West African vegetables like okra and yams along with root crops and condiments for their stews and other dishes. Their leaders and priestesses still display economic competence and courteous manners as they direct their various seitas (sects). These seitas are fetish cults, complete with orishás (a term which originally meant pagan deities but now includes the cult's priests), like the black witch doctors who practice popular medicine in Bahia. The "daughters" in the candomblés are still active in Brazilian life and they perform, sometimes with the sect's junior members, the batucada dance in these ritual assemblies.

These quilombos were constantly springing in the backwoods, and their members perpetuated their tribal customs. The "comrades" or "buddies" who lived in these camps were known as mulangos, and were participants in a vigorous popular movement with serious and dignified rituals.

\section{$* * *$}

Over time, several mucambos (forest kingdoms or republics) emerged on the South American continent. These entities lived by their own laws and displayed a remarkable spirit of independence, especially in the depths of the Brazilian coastal forests. The ideal mucambo sat on a mountain top, like the favelas of contemporary Rio de Janeiro which may be their lineal descendants, while the first recorded quilombo was established in 1579 in the captaincy general or state of Bahia, directly opposite West Africa. Thus fifty years after the Portuguese came to Brazil, there was a settlement comprised of several hundred fugitive slaves, a large number for those early days of initial settlement (if we can trust these "statistics").

In 1602, the first expedition was planned against these so-called "bush Negroes." Many subsequent forays were dispatched in an attempt to conquer them, for the Portuguese felt that the presence of free African settlements in the backwoods was a menace to the practice of slavery in their colony. If the escaped slaves were from West Africa (i.e., Fulani, Hausa, or Mandingo), then the possibility that either they or their ancestors had been Muslims with a long tradition in the emancipating culture of Islam was great. The spirit of rebelliousness manifested by the Brazilian slaves spread the fear of Muslim 
unification. A similar fear was seen in the United States with the rise of the Black Muslims in the 1960s and 1970s. The result in both countries was also similar: police action against and suppression of those who were voicing their dissatisfaction.

The strongest recorded movement of slaves in Brazil seeking to escape their enslavement is seen in the Palmares epic. This refers to the so-called "Palm Tree Republic" or kingdom, an entity that symbolized African resistance to slavery and social injustice. Palmares was established in the Serra de Barriga, an area lying between the present states of Pernambuco and Alagoas. This African-style community lasted from approximately 1630 to 1697 or, if its survivors are counted, even longer. Since the movement left no records of its own, or such records were either destroyed or lost, all of the figures given here are estimates.

Spontaneous flights to the bush in the highlands of Palmares increased as word of it gradually spread through the senzalas (slave quarters) on the sugar plantations of Alagoas, Pernambuco, and even Bahia. The character of the uprising in the Palmarine uplands was marginal; it is a region of heavy rains at times and then of prolonged drought, a cycle that has afflicted the tragic northeast of Brazil for centuries, just as drought often cripples the Sahel region of West Africa. The Palmarine social organization was based on a loose confederation of fortified villages. It is estimated that up to thirty thousand people lived in these quilombos located in the Serra da Barriga. Its political organization was that of a republic patterned largely on the inland kingdoms of West Africa. It enforced its own laws, held popular assemblies, and established a federation of outposts throughout the hilly country found in this part of Brazil. The present town of Orobó (now called Rui Barbossa and located in Bahia state) was one of these runaway hideouts which was able to survive into this present century.

In many of these quilombos, the ex-slaves spoke their own dialect. Communal landholding seems to have been based on West African models. They had many children, the first offspring of freedom in Brazil. The republic carried on a mainly barter-based trade with neighboring coastal settlements, as no coinage or any formal money was ever created. This trade centered on the exchange of mainly agricultural commodities for manufactured goods brought in from overseas. Although everybody lived from the fruit of his/her own work, communal trading was the norm. Millet, beans, manioc, sugarcane, and other vegetables were grown for food. They also raised chickens but apparently had few cattle, which makes us wonder how many of them were Fulani or Fulbe (i.e., a major occupation of these tribes in their native lands).

Palmares was a properly policed state with laws of its own based mainly upon West African traditions and customs. Adultery, theft, and desertion were punished with death. The community levied taxes for public services and had 
both civil and criminal laws. The Palmarines managed to raise an army for self-defense (one of the true tests of statehood in modern international law) and relied on flying columns for the purpose of attack. Their political and social institutions were better than those that governed the Canudos movement two hundred years later, by which time much of this tradition had been lost.

$\star \star *$

The principal leader of Palmares was Ganga Zumbi (not to be confused with one of his nephews, who bore the same name and played a role in the final resistance to the Portuguese). This may be an Angolan name, although Ganga Zumbi himself was more probably an Ewe, meaning that his parents had come from present-day Togoland or Ghana. The republic which he led attracted Brazilian Indians and poor whites as well as blacks, just as Canudos did two centuries later, and fought off both the Portuguese and the Dutch, who were then fighting each other for control of all of Brazil.

To the north of Palmares lay the captaincy general (and later state) of Pernambuco, which was settled in 1534 and had since grown wealthy due to its sugar estates. Incidentally, the name of its capital city, Recife, which was at that time the capital of Dutch-occupied Brazil, comes from the Arabic word rașif, meaning "pier" or "dock."

The Palmarine revolt broke out in full force between 1630 and 1640, during the Dutch occupation of northeastern Brazil, and was not easily quelled. Before the Dutch were forced out by the Portuguese, they had launched over twenty major attacks on Palmares. Their successors, the Portuguese, sent many fruitless expeditions into the bush country, one in 1670 and another in 1677 to mention a few. Five years later, another expedition was planned. In all, fifteen campaigns were sent against this black African republic/ kingdom.

When Ganga Zumbi (or Samba), the leader/king of the Palmarines, first entered the picture, he was a young Ewe (or Arda in another account) of Gold Coast stock. He is described as "a brave Black with great presence of mind and an interesting faith," although what faith this was is not clear. The Portuguese considered him a rebel and an upstart (he is regarded as a great historical figure by the contemporary Brazilian movie industry) and called their own movement to contain him a "crusade," thus giving their counterattack a semireligious character. This was in line with the official position of the Catholic church in Brazil, which pronounced itself in favor of slavery. The celebrated Jesuit orator Antônio Vieira advised the Portuguese king to maintain the institution of slavery, spoke out against this Palmarine insurrection, and attempted to use philosophy to justify and legitimize slavery just as Bishop Las Casas had done a century and a half earlier for the Spanish throne. Eventually, Vieira fashioned the Portuguese Catholic church's doctrine on slavery into a complex and baroque "harmony." 
Ganga Zumbi is said to have been born in 1735 in Porto Calvo on the northern coast of Alagoas. His slave name was Francisco. Before the end of his campaign, he had become a grandfather and was said to have a white wife as well. He had a "palace," called Ganga-Songo or Zona, but we are not told whether this was a name, a title, or a mere nickname. Zumbi's capital was called Macacos, which means "monkeys" in Portuguese. This town was located in the Serra da Barriga, and contained five hundred houses and eight thousand inhabitants, according to one estimate. The frivolous name for the capital makes one suspect that this was merely a derisive nickname; we must always remember that whatever we know about the Palmares republic is what the Portuguese, its enemies, have transmitted to us, for Palmarine records are nonexistent. Some writers place the total number of inhabitants at thirty thousand. The number varies because of our lack of reliable statistics.

The town of Macacos was fortified either by a mud wall similar to those used in West Africa or by a stockade or palisade which made it into a real fortress. Its packed-clay houses were built from red earth and had palmthatched roofs, although some settlements featured wooden houses. Macacos must have been a somewhat ramshackle place at its height, for it contained a labyrinth of streets and lanes with little urban planning. The city lay two hundred miles from the coastal towns of Serinhaém, Porto Calvo, and Alagoas, and could only be reached by going through the wooded mountains rising behind the Atlantic seaboard.

Ipojuca may have been the first town founded by these African freedom fighters. Amaro, a settlement of five thousand people, lay thirty-five miles northwest of Serinhaém. Sucupirá, another settlement, was said to be the second largest. Arotirene may have been their largest town. Numbering some six thousand inhabitants, it lay about sixty miles from Alagoas, the seat of the Brazilian captaincy directly south of Pernambuco. Each of these major settlements had several streets lined with wooden or adobe houses covered with thatched roofs. As many as eight hundred were counted in each settlement on the first scouting expedition sent inland by the Portuguese. Each town was surrounded by tilled fields to guarantee its food supply. Other towns were Tabocas, Dambranga, Cerca Real do Macaco, Osenga, and Antalquituse.

Bush captains named by the Portuguese were used to combat the Palmarines. In 1674, an army captain by the name of Dom Pedro de Almeido initiated a policy that led to the signing of a peace treaty between the Portuguese and the Palmarines. Four years later, three of Zumbi's sons came to the colonial capital of Recife to treat with the Portuguese authorities. Four months later, Zumbi came in person, along with a train of forty people, and agreed to a peace treaty between himself and the Portuguese authorities.

In 1694, the republic/kingdom of Palmares almost achieved its independence from the Portuguese. King Zumbi, as he was now called, survived an 
assassination attempt (he was stabbed in the stomach) the following year and soon had to confront the Portuguese once again. Half-breed soldiers trained as Indian hunters were soon brought north from São Paulo to assist the Portuguese army. These people were called mamelucos, an obvious derivation from the Arabic term mamlük, meaning "owned" or "possessed" by someone else as chattel. In this instance, however, the Brazilian word describes the result of a direct European-African union. The name also recalls the military slaves whom the Turks recruited for use in Ottoman-ruled Egypt.

Since the Palmarine capital of Macacos was fortified, the colonial authorities decided to launch a general assault. In order to get their cannons into position, a carriage road was laid from Porto Calvo, located two hundred miles away towards the Atlantic coast. In Pernambuco, a rumor circulated that a "Moor" had undertaken the fortification of Macacos, just as Salmān al Fārsī had strengthened Madinah for the Prophet with a trench or moat before the battle of Uhud.

This three-year campaign became a prolonged war in the backlands and resulted in the complete destruction of the heroic African republic/kingdom. By 1697, the Palmarines were defeated, starved, and stamped out in "one of the most unremunerative bits of pillaging that history has to record" according to the Brazilian writer Euclides da Cunha. This same author, in his Os Sertões (Revolt in the Backlands), gives $1630-97$ as its inclusive dates.

The Portuguese treated King Zumbi's corpse in a barbarous fashion: they cut off his head and private parts and mutilated his corpse before publicly displaying it in Recife. The prisoners of war captured in the first onslaught were sold in the far northern parts of Brazil, mostly in the coastal captaincy (province) of Maranhão, in the hope that they would be unable to find their way back to their former comrades in arms. Those who had survived the destruction of Palmares were finally wiped out in 1713, almost a generation later.

At times, the gift of freedom seemed to be almost a punishment in Brazil, for the emancipados (lit. "freedmen") were simply set free to starve (as they were in England, Nova Scotia, and the United States). In Alagoas, the airport at the present state capital of Maceió is called Palmares, as if in memory of these early freedom fighters. Palmares is also the name of a town southwest of Recife in Pernambuco.

\section{$* * *$}

Following the defeat of the Palmarines, continuous revolts occurred in the Brazilian hinterlands. In 1704, another insurrection on the Palmares model broke out, this time in Campoanga in the Serra Negra to the north of Recife. Unrest also occurred at Cumbé, Paraiba, during the early eighteenth century. In 1719, still another insurrection took place in the new inland state of Minas Geraes (lit. General Mines) in the mining district which the Portuguese had 
opened up (the first gold strike in Minas Geraes took place in 1695, towards the end of the Palmares episode). In 1763, another slave insurrection broke out around Bahia.

After 1803, rumblings of the not-too-distant Malê revolt began to be heard as black Muslim unrest began to spread around Bahia. An Ussa (Hausa) revolt occupied the Brazilian authorities during 1807-9; an uprising occurred in the state of Espíritu Santo during the early 1800s; Rio de Janeiro was plagued during 1823-24 and again in 1876 with lawlessness; in 1830 and 1832 still other insurrections broke out in Bahia, at Ilhéus, a coastal city to the south of Salvador, the chief port and capital of Bahia; and Maranhão to the north suffered unrest in 1853. The determination and despair of the AfroBrazilians to better their lot was evident in these widespread rebellions.

Urban revolts took place from 1803 until 1835 in Salvador, where events came to a head. However, it had no real leadership. During 1828 and 1830, some forerunners of the Malê revolt were heard around Bahia, including its port and capital city of Salvador, as well as in other coastal ports where the Muslims wanted freedom to practice their own religion, the right not to have to bow down before the tamäthil (graven images) of the Catholic saints, and the related right of not having to bear the litters of the tamäthil during religious processions.

The Malê movement bears the focal date of 1835 in history books and newspapers. On the night between January 24 and 25, this revolt of the Africans and their descendants broke out in the streets of Salvador and presented a direct threat to the Brazilian soldiers and police. This was the result of an underlying unrest which had been brewing for weeks in the coastal cities. The Malê movement thus dates from approximately 1831 till 1837. It was a sullen rebellion that spread along the coast through central Brazil, a South American version of the thawrat al zunūj ${ }^{1}$ (lit. revolt of the blacks), which instilled a fear of the Muslims within the Brazilian upper class and army.

In a way, this rebellion reflected the resentment of Africans who had been cut off from their cultural roots and forced to subscribe to a faith in graven images rather than one in God alone. It is generally called the Great Male Revolt of 1835 because the Mandingos from Mali had kept their Islam alive during their centuries-long exile from Africa. These rebels opposed the grosser forms of Christo-pagan image worship and the fact that they were not permitted to practice their Islamic faith freely and to worship God alone. The Ûssa slaves often knew the Qur'an by heart, but the Brazilian establishment and police did not allow them to read it or to practice their religion. In a gen-

'The original thawrat al zunüj occured in the date groves around the port of Basrah in southern Iraq during the ninth century C.E. Its adherents were East African slaves. The Qarāmitah (Carmatians) living in Saudi Arabia's Eastern Province are their restless descendants. 
eration or two, such knowledge lingered on merely as part of their descendants' folkloric memories, as it does in the United States as well.

Religion played a clear and central role in this uprising, the defeat of which engendered the deportation of hundreds of Africans from Brazil and wide-spread massacres of its adherents. The Afro-Brazilians were tired of bowing down before saints and images and of being forced to subscribe to the irmandades (blasphemous cults) dedicated to semideities, which they rightly regarded as a deviation from the worship of the sole God. The pagan "fraternities" or "brotherhoods" that the slaves were encouraged to join repelled the Muslims, for they felt it was blasphemous to talk about a "mother of God" and other such things.

This issue, like the seventeenth-century uprising in Palmares, formed a proletarian movement which compensated for the Africans' feeling of unrest and suppression. These nineteenth-century freedom fighters fought tenaciously against the whole Brazilian army, just as their ancestors had fought the Dutch and Portuguese armies a century and a half before. Soon after the defeat of the revolt, from 1839-41, a balaida (lit. sweep) through the northern coastal state of Maranhão was launched by the Brazilian authorities. Such revolts have plagued Brazil more frequently than in the United States or the West Indies. Palmares, Malê, and Canudos all require sympathetic study in order to explain the deep-rooted religious dissent of these oppressed Muslims and their descendants.

The leaders of these nineteenth-century rebellions, when they were not massacred, were shipped back to West Africa by the hundreds. These Brazilian emancipados were frequently Muslim. The Salvador mosque in Lagos, with its unique Portuguese style of architecture and craftsmanship, was built by them and is maintained by their descendants. Freedmen arrived in Nigeria and other ports along the Gulf of Guinea coast as tradesmen who knew many useful crafts, for they had been trained as carpenters, masons, cobblers, and bakers and so on during their harsh and lonely exile overseas. Some of them even had acquired some fluency in Portuguese and English.

\section{$* \star *$}

Religious dissidence pervades Brazilian society. Its most spectacular manifestation is the paganism and license observed during the Rio carnival, as well as its smaller counterparts scattered throughout the region. The Peruvian novelist Mario Vargas Llosa wrote a book, The War at the End of the World, about what happened in 1897 in the isolated settlement of Canudos in the western part of Bahia state. This story follows Euclides da Cunha's Os Sertões (Revolt in the Backlands), which describes life on the Brazilian frontier (similar to that of the pioneers in North America). Its heroic resistance lasted for nine years and was packed with memories of civil and religious 
oppression that spanned three centuries. The movement's leader was Antônio Conselheiro, and his rallying call of "Allāhu Akbar" brings us an echo from Brazil's Islamic past. The French film "Black Orpheus," which was based upon this incident, reflects a similar but pagan movement in Rio de Janeiro.

Gilberto Freyre, a distinguished Brazilian sociologist and long-time native resident of Recife, devoted his life to studying this Afro-Brazilian culture. In 1934, an Afro-Brazilian congress was held under his patronage in Recife and, in 1937, another one was held in Salvador, Bahia's capital and chief port. Freyre's perceptive studies observe the racial interaction that has taken place within Brazilian society. His novel Casa Grande e Senzala (Big House and Shacks; also known as The Master and the Slaves) records similar research. Nina Rodrigues, a Brazilian anthropologist, wrote Os Africanos no Brasil (Africans in Brazil) and had it published in São Paulo in 1933. The following year, Pedro Calman wrote Os Malês: a Insurreção das Senzalas (Men of Mali: The Uprising in the Slave Quarters). In these studies, Brazil's culture is shown as a fusion of African, European, and native Amerindian sources.

Police action interfered continuously with the Afro-Brazilian religious ceremonies, recalling the rigors of the Spanish Inquisition as well as the recent Western police state. French anthropologists, apparently basing their models on the one employed by the French during their occupation of Algeria, and Brazilian police seek the same negative results in their research: they rarely find any Muslims in the society which they are studying! For example, the sociologist Roger Bastide showed a grave lack of perception during his fieldwork in Brazil, for he was blind to Islam and to the presence of local Muslims. Such research results in publications bearing more relation to science fiction in the service of cultural imperialism, as has been the case with various biased orientalists studying the Islamic world in general, than it does to real academic research. For example, in his book The African Religions of Brazil, ${ }^{2}$ Bastide talks loosely of both "Mussulmans" and "Mohammedans" and slights or ignores any Islamic traces in Brazilian culture. When his nomenclature is not respectful, what can one expect from his conclusions or even his total research? Clyde Ahmad Winters, an Afro-American anthropologist who worked in Rio de Janeiro, has reported more broadly on this field.

Brazilian conditions run in deep patterns: the turbulent wandering in the backlands influenced the lower classes, just as the so-called "frontier" did in North America. The Brazilian backwoodsmen were similar to the North American "pioneers" or the French Canadian voyageurs. The Canudos incident, which took place in the far western interior of Bahia state in 1897, came fully two hundred years after Palmares and less than a century ago.

\footnotetext{
${ }^{2}$ Roger Bastide, The African Religions of Brazil (Baltimore: Johns Hopkins University Press, 1978), $143 \mathrm{ff}$.
} 
During the middle 1800 s, Brazil's slave-based plantation economy began to crumble. Although Brazil had agreed to abolish slavery as early as 1831 , trafficking in slaves continued until 1851. Agitation for its total abolition began in the 1860 s, and was met with resistance by the Brazilian landlord class which formed the country's social and economic elite. This led to technical stagnation becoming deeply rooted in Brazil, a development which was replicated in the West Indies and the southem United States, all of which had outmoded methods of production. The decline of the sugar industry, along with the beginnings of mechanization, the influx of new European immigrants, increased skill levels in the general labor force, and the growing social and economic liabilities associated with slavery were all contributing factors to slavery's decline. On 13 May 1888, Princess Isabel, serving as the regent of Emperor Pedro II (her father) while he was in Europe, signed a document abolishing the very institution of slavery. ${ }^{3}$

This period marks the return of many former Afro-Brazilian slaves to the Gulf of Guinea coast: between 1850 and 1878, several thousand emancipados (slaves who had brought their own freedom) settled in the ports of Lagos (Nigeria) and Porto Novo and Whydah (Benin). Many families in those cities remain proud of their Brazilian antecedents and bear Portuguese surnames like da Silva, Santos, or Fernandes. Their fondest wish had been to return to Africa. The complete history of these brave souls still needs to be recorded.

Many of the emancipados were encouraged by the Brazilians and the British to return to Africa, just as North American freedmen had been, especially after the great Malê uprising of 1835 . Relations were strong between the ports of Salvador and Whydah (or São João de Ajudà, to give it its Portuguese name) on the Dahomey (present-day Benin) coast. Many educated freedmen settled down in Lagos, a port which began to flourish after the 1860 s, and became prominent citizens. This development was especially true of those who brought with them such useful skills such as tailoring, shoemaking, carpentry, and bricklaying. These Portuguese-speaking emancipados have left their names all along the Gulf of Guinea coast, especially in the Bight of Benin. Lagos itself means "lakes" or "lagoons" (the Portuguese-language description of its physical location); Porto Novo (New Port) is Benin's capital city; and other towns are named Porto Seguro (Safe Port) and Escravos (Slaves).

Only the final emancipation of the Brazilian slaves in 1888 brought a partial respite from this mood of unrest and discontent. But even then, Canudos was to remain as a sullen postscript. This revolt consisted of a real war in the bush. It was, moreover, a popular movement which has confounded those historians and political scientists who have attempted to explain it despite their

${ }^{3}$ Independence for Brazil came in 1822 under Emperor Pedro I, when he proclaimed: "Eu fico! ("I remain") - in Brazil rather than return to Portugal as his father had wanted. 
meager understanding of its West African and possibly Islamic background. The religious content evades such contemporary scholars, as happens with most sociologists who study African movements today. As a result, these true heroes who struggled so bitterly and keenly for their freedom are remembered only at Carnival times. This entire historical episode has become a romantic legend in Brazil, drawn from the folklore surrounding the period of Carnival. Some recent films dealing with the movement have been made by the cinema director Carlos Diegues.

Due to this continued unrest, the Brazilian ruling classes became wary of any Islamic-based movements. Brazilian landowners, incensed at Princess Isabel's abolition of slavery, soon turned to the army, which proclaimed the Brazilian republic in 1889 . The republic proved to be even more reactionary in many ways than the imperial Bragança family had been: republican government does not necessarily ensure progress or liberty, while monarchy can act as a stabilizing influence between different sectors in society and thereby protect human freedom, as in Scandinavia, Britain, Canada, and Japan.

The Brazilian ruling classes nonetheless maintained their wariness of Islamic-based movements like the Malê uprising. When, in 1897, the dissidents of Canudos deep in the western part of Bahia rose in revolt under the cry of "God is Great" (lit. Allāhu Akbar in Arabic; Deus ê Grande in Portuguese), the Brazilian army moved in and slaughtered twenty-five thousand people. Only four ragged men were left alive after this genocidal incident at Canudos, an abandoned cattle ranch that had become the center of a religious movement. Thus, still in this movement we can see a memory of the slogan that their ancestors had known on the high savannas of West Africa.

\section{$* * *$}

The distribution of occupations and trades in both Brazil and the Caribbean area was broad. African slaves were the actual builders of Brazil, the hewers of wood and drawers of water, just as their fellow slaves formed the basic labor force in the West Indies and the North American "South." Small farmers and artisans could move up more easily in Brazilian society than they could in the southern (and northern) United States. In the interior backlands of Brazil, they became stock breeders and small farmers, showing their Fulani talent in handling cattle. As masons, carpenters, house painters, cabinetmakers, cobblers, mechanics, printers, tinsmiths, iron workers, and stevedores, they offered their services in the cities and ports of Brazil, while as soldiers and actors they strutted their way through the towns in the hinterland. The iron-smelting skills which the Ûssa slaves had introduced into Brazil were also projected into the nation's incipient industry as well.

Mulattos found more chances for education in Brazil than did their counterparts elsewhere. Due to this opportunity to increase their knowledge, 
with the added benefit of greater mental alertness, some were able to work their way up the Brazilian social hierarchy. Mulattos trained as physicians, lawyers, or singers could, if qualified, find more scope to lead productive lives in Brazil than could their brothers and sisters in the United States. In fact, this segment of Brazilian society produced many physicians, lawyers, and engineers for the new society that developed in independent Brazil. However, many remained as marginal characters. Like the North American exslaves who fled from the southern countryside to the northern industrial cities, the inhabitants of northeastern Brazil spread south and west, losing more cultural patterns through slum living in the favelas and with dull manual or factory jobs, both of which could be as degrading and monotonous as life on the old plantations had been. One benefit of this social mobility has been a gradual process of social leveling, which has allowed Brazil to view itself as a relatively stable society, at least for the present.

By 1905, before all of the Afro-Brazilians actually born in Africa had passed away, one-third of all ex-slaves and their descendants who lived in the state of Bahia were said to be Muslim; by 1910, it was calculated that at least twenty to thirty thousand Muslims still lived in Brazil. Small groups of Muslims are found today in Rio de Janeiro, Bahia, and São Paulo. In addition, the Palestinian diaspora has resulted in new Muslim immigrant communities appearing in Brazil's southern cities as well as, generally speaking, throughout South America.

T. B. Irving The Mother Mosque Foundation Cedar Rapids, Iowa

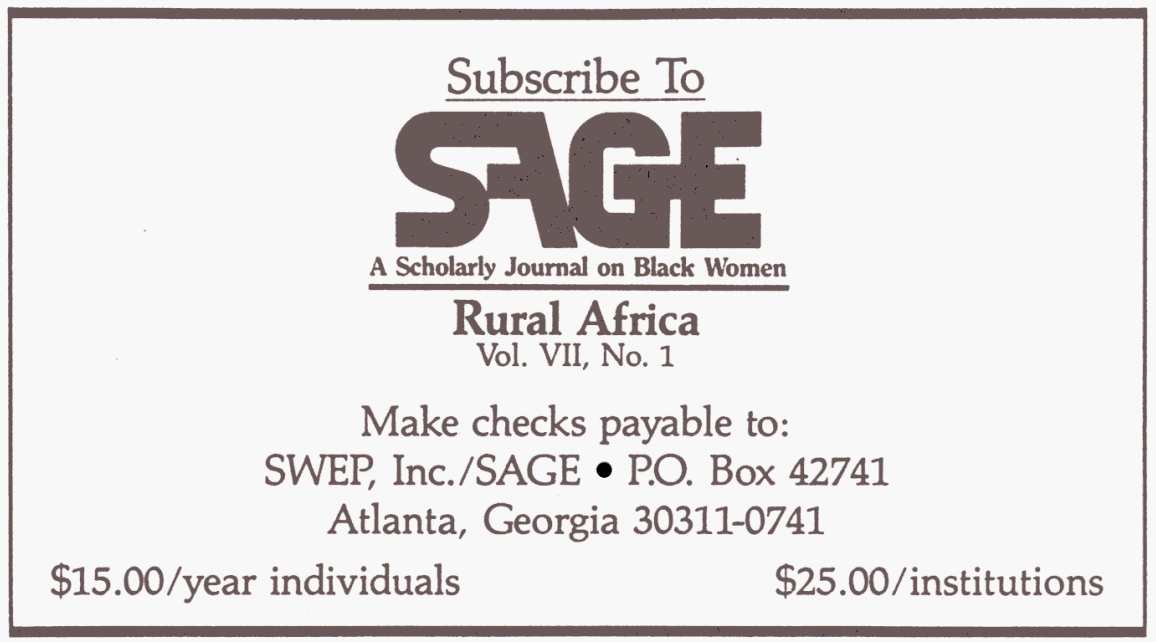

